\title{
WORKING CONDITIONS AND SATISFACTION WITH WORKING CONDITIONS AMONG SLOVENIAN FAMILY MEDICINE TRAINEES: A CROSS-SECTIONAL STUDY
}

\author{
DELOVNE RAZMERE IN ZADOVOLJSTVO Z NJIMI MED SLOVENSKIMI \\ SPECIALIZANTI DRUŽINSKE MEDICINE: PRESEČNA ŠTUDIJA
}

\author{
Klemen PAŠIĆ' ${ }^{1,2}$, Vojislav IVETIĆ1,3* \\ ${ }^{1}$ University of Maribor, Faculty of Medicine, Department of Family Medicine, Taborska ulica 8, 2000 Maribor, Slovenia \\ ${ }^{2}$ MEDIKUS d.o.o., Cesta k Dravi 8, 2241 Spodnji Duplek, Slovenia \\ ${ }^{3}$ SAVA MED d.o.o., Cesta k Dravi 8, 2241 Spodnji Duplek, Slovenia
}

Received: Feb 20, 2021

Accepted: Jun 30, 2021

Original scientific article

\section{ABSTRACT \\ Keywords: \\ family medicine, primary healthcare, trainees, working conditions, satisfaction}

\section{IZVLEČEK}

Ključne besede: družinska medicina, primarno zdravstveno varstvo, specializanti, delovne razmere, zadovoljstvo
Introduction: In order to achieve a high standard in training programmes for future family medicine specialists, it is essential to have good tutors with well-organised family medicine practices. Proper working conditions for young doctors are essential for their satisfaction and future professional development. The aim of our study was to check the current working conditions of family medicine trainees in the practical modular part of the training programme in Slovenia, and to determine their satisfaction with working conditions.

Methods: A cross-sectional study was conducted. The data was collected through a questionnaire distributed to 105 family medicine trainees undergoing the practical modular part of their training programme.

Results: The study showed that the following 7 out of 25 organisational and labour law factors are significantly associated with a trainee's general satisfaction with working conditions: the location where work with patients takes place, the privacy of the premises, the accessibility of the main tutor, a constant patient population, suitable places for rest, paid out-of-hours substitutions, and appropriate pay grade.

Conclusion: The results we obtained can be used to address certain aspects of trainees' working conditions in Slovenia that need improvement. By determining which working conditions significantly affect a trainee's satisfaction, we have the opportunity to modify these conditions and thereby improve the training programme. This could result in a less stressful and more efficient residency programme.

Namen dela: Družinska medicina predstavlja enega od ključnih dejavnikov organizacije vsakega modernega in kakovostnega zdravstvenega sistema. Ob tako pomembni nalogi, ki jo v zdravstvenemu sistemu skuša uresničevati družinska medicina, je smiselno pričakovati ustrezne delovne razmere, $k i$ vključujejo tudi kakovostno izobraževanje bodočih specialistov družinske medicine. Pri tem so izjemnega pomena dobri mentorji in primerna organizacija ustanove, ki lahko mlademu zdravniku v svojih ambulantah zagotovi ustrezne pogoje dela. Namen naše raziskave je bil preveriti delovne razmere slovenskih specializantov družinske medicine $v$ ambulantno-modularnem delu specializacije in izmeriti njihovo zadovoljstvo delovnimi razmerami.

Metode: Uporabili smo presečno obliko študije. Podatki so bili zbrani z tridelnim vprašalnikom, ki je bil razdeljen 105 slovenskim specializantom družinske medicine ( $v$ tem trenutku 29,75 \% vseh specializantov družinske medicine $v$ državi) $v$ ambulantno-modularnem delu specializacije. Prvi del vprašalnika se je nanašal na sociodemografske značilnosti specializantov družinske medicine, drugi del pa na delovne razmere, $v$ katerih opravljajo program specializacije. Poudarek je bil na mentorstvu, zagotavljanju ustreznih prostorov in opreme za diagnostiko ter redno delo, ureditvi ustrezne zasebnosti pri delu, srečanju z regionalnim koordinatorjem, uporabi računalnika, ustreznih izobraževanjih, uporabi poklicnih kartic, ustreznem plačnem razredu ipd. Tretji del ankete je vseboval vprašanja o zadovoljstvu zaposlenih (notranji odnosi, motivacija in zavzetost, občutek pripadnosti instituciji, struktura organizacije, strokovna usposobljenost in učenje, zavedanje poslanstva, vizije in ciljev, notranja komunikacija in informacije).

Rezultati: Raziskava je pokazala, da je naslednjih 7 od 25 organizacijskih in delovnopravnih dejavnikov pomembno povezanih s specializantovim splošnim zadovoljstvom delovnimi razmerami: lokacija dela s pacienti, zasebnost prostora, dostopnost glavnega mentorja, stalnost populacije bolnikov, ustrezen prostor za odmor, plačana nadomeščanja izven delovnega časa in ustreznost plačnega razreda.

Zaključek: $V$ raziskavi smo predstavili delovne razmere slovenskih specializantov družinske medicine $v$ ambulantno-modularnem delu specializacije. S pridobljenimi rezultati lahko opozorimo na določena slabša področja delovnih razmer specializantov in s tem vplivamo na njihovo izboljšanje. Ugotovili smo, katera področja delovnih razmer pomembno vplivajo na zadovoljstvo specializantov družinske medicine $v$ Sloveniji ter $s$ tem pridobili priložnost za predlaganje sprememb in $s$ tem izboljšanje samega programa usposabljanja. Posledično bi lahko povečali učinkovitost poteka specializacije in predvsem zmanjšali stres pri specializantih. 


\section{INTRODUCTION}

In their work, family medicine physicians (FMPs) use a comprehensive approach and specific problem-solving methods leading to person-centred healthcare and concurrent management of several problems $(1,2)$. The healthcare system in Slovenia, like in most European countries, considers the FMP to be a gatekeeper and coordinator, in line with the principles of the World Health Organization (3), thus imposing on them a great responsibility towards their patients. Since 1992, the FMP's private practices have provided equivalent and equal services to those provided by public healthcare institutions (3).

Employee satisfaction refers to a distinctly positive emotional state resulting from how an employee perceives work, how they understand and consider their working environment and their work experience, and the way they comprehend all the elements of their work and job (4). These perceptions are influenced by the work itself, co-workers, superiors, salary, etc. (5). Different authors provide various definitions of work satisfaction factors $(5,6)$. Good working conditions and appropriate high-quality work assets act as a motivating force for employees $(7,8)$. The studies also reveal many work-related motivational factors (9).

In the course of a young physicians' education, tutorship is essential, since several studies have demonstrated the tutor's impact on the future career of a student or physician $(10,11,13)$. A better tutor-trainee relationship positively impacts the trainee's subsequent career $(12,14,15)$ and improves clinical abilities (16-21). On the other hand, a dysfunctional relationship with the tutor might negatively impact the trainee's professional development (17).

In Slovenia, completed specialist training in family medicine has been mandatory since 2000 for independent work at a family medicine practice (22). According to the current programme in force since 2015, the training lasts for 4 years, of which 2 years are for the clinical hospital rotation and 2 years for the practical modular part (practical work in family practice with 20 educational courses - two days per month) (3). For a family medicine trainee (FMT) in Slovenia, working with a main tutor is mandatory throughout the specialist training, both during the clinical part and during practical work in family practice (3). Competent performance by FMTs can only be realised in medical practice when many different conditions are met $(3,23)$.

Detailed studies outlining the working conditions for FMTs, either in Slovenia or other countries, were not available during our study while the literature was being reviewed. The purpose of our study was to determine working conditions for the FMTs during their work at family practices and establish the level of FMTs' satisfaction with their working conditions.

\section{METHODS}

\subsection{Study design}

This was a cross-sectional study. A three-part questionnaire was used for data collection.

The first part of the questionnaire concerned the sociodemographic characteristics of the responding family medicine trainees. We inquired about gender, age, marital status, location of medical studies, employment and work at the community health centre or practice with the concession (individual contractors with National health insurance), employment of the main tutor, number of trainees at the institution or concessionaire, and number of trainees overseen by the main tutor.

The second part enquired about the trainee's working conditions. The focus was on the tutorship, provision of suitable premises and equipment for diagnostics and regular work, level of appropriate privacy at work, meeting with the regional coordinator for specialization of family medicine, computer use, appropriate training, professional card (national ID card for healthcare professionals) use, appropriate pay grade, etc.

The third part of the employee satisfaction survey contained a part of the questionnaire on employee satisfaction in the model practice (MP) (24), prepared by the MP project council (24). A model practice is a family medicine practice additionally employing a registered nurse providing more effective management and monitoring of chronic patients and provision of preventive check-ups for patients aged over 30 (24). 27 statements were used concerning the organisational atmosphere to investigate its various dimensions (internal relations, motivation and commitment, sense of belonging to the institution, structure of organisation, professional competence and learning, being aware of the mission, vision and goals, internal communication, and information).

A direct question regarding the satisfaction with working conditions was also asked. Opinions regarding the statements in this part were specified using the level of agreement, such as the five-point Likert scale (ranging from 1 = strongly disagree to 5 = strongly agree).

Following the example of another studies $(29,31)$, the adequacy of working conditions was defined according to spatial requirements, the availability of necessary equipment, and the requirements of the specialist training. Further on, the differences in the trainee's general satisfaction with working conditions in relation to specified working conditions were analysed based on the pre-specified adequacy values.

A family medicine trainee should have properly equipped premises available and providing a suitable degree of privacy. The following issues are important: access to their own computer, protective clothing, a constant 
patient population, their own location for work, appropriate consultation, and the internet, as well as completing appropriate training modules before starting work (occupational safety, fire safety, hospital infections, etc.), time to rest (annual leave, lunch breaks, etc.), and whether they work during their entire specialist training as a substitute, on behalf of someone else. In the latter case, the option of following up on work quality is lost, which prevents the advancements in knowledge and the mastery of competencies set out by the specialist training programme $(4,9)$.

\subsection{Selection of study subjects}

During data collection (between September 2016 and December 2016), 353 family medicine trainees were working in Slovenia. The analysis included 105 trainees who had been randomly chosen among all 353 (29.75\%) Slovenian family medicine trainees. 93 of them were invited to participate while they were undergoing the practical modular part of their specialist training members of modular groups 17, 18, 22, 23 (trainees from all Slovenian regions). An additional 12 trainees were included from the Maribor region at the time their regional meeting took place (which is also a mandatory part of the practical specialist training module). The trainees completed anonymous paper-based questionnaires. We also obtained participants' verbal informed consent for their participation in our study. Everyone participated who had been invited to participate or received the questionnaire.

\subsection{Statistical analysis}

Statistical data analysis was performed using the IBM SPSS 20.0 statistical package. In accordance with the standards of statistical analysis, critical examination of the raw data and a logical control procedure was performed. During our critical examination, there was no replacement of missing values. The statistical significance level was set at $5 \%$ $(p<0.05)$. Basic descriptive statistics were used to analyse the basic profile of family medicine trainees. In order to check the study questions, depending on the specified type of variables and on the (non-)normality of distribution, corresponding parametric and non-parametric tests were used, such as the t-test, $\mathrm{x}^{2}$ test, Mann-Whitney test and Kruskal-Wallis test. The Shapiro-Wilk and KolmogorovSmirnov tests were used to verify the normality of data distribution. Adjusted standardised residuals were used to determine categories that considerably contribute to the significance of differences.

\section{RESULTS}

\subsection{Sociodemographic characteristics of trainees}

The average age of the responding trainees was 29.8 years (min. 25, max. 45). 22.1\% $(n=17)$ were 29 years old. The proportion of women among the trainees was high, 84 out of $105(80 \%)$. Sociodemographic characteristics are provided in Table 1.

Table 1. Sociodemographic characteristics of FMTs.

\begin{tabular}{|c|c|c|}
\hline & Number (n) & Proportion (\%) \\
\hline \multicolumn{3}{|l|}{ Gender } \\
\hline Male & 21 & 20.0 \\
\hline Female & 84 & 80.0 \\
\hline \multicolumn{3}{|l|}{ Year of specialist training } \\
\hline First & 45 & 42.9 \\
\hline Second & 17 & 16.2 \\
\hline Third & 37 & 35.2 \\
\hline Fourth & 6 & 5.7 \\
\hline \multicolumn{3}{|l|}{ Environment of the practice } \\
\hline Urban & 50 & 48.1 \\
\hline Suburban & 27 & 26.0 \\
\hline Rural & 27 & 26.0 \\
\hline \multicolumn{3}{|l|}{ I am employed } \\
\hline $\begin{array}{l}\text { at the community health } \\
\text { centre and I work at the } \\
\text { community health centre }\end{array}$ & 88 & 83.8 \\
\hline $\begin{array}{l}\text { at the community health } \\
\text { centre and I work at } \\
\text { the concessionaire }\end{array}$ & 2 & 1.9 \\
\hline $\begin{array}{l}\text { at the concessionaire and } \\
\text { I work at the community } \\
\text { health centre }\end{array}$ & 1 & 0.9 \\
\hline $\begin{array}{l}\text { at the concessionaire and I } \\
\text { work at the concessionaire }\end{array}$ & 14 & 13.3 \\
\hline \multicolumn{3}{|l|}{ Main tutor location } \\
\hline $\begin{array}{l}\text { at the community } \\
\text { health centre }\end{array}$ & 81 & 77.1 \\
\hline at the concessionaire & 24 & 22.9 \\
\hline
\end{tabular}

\subsection{Basic characteristics of family medicine trainees according to working conditions}

The overview of the basic characteristics of FMTs according to working conditions showed that on average there were 3-4 trainees per institution (30.5\%), and 2 per main tutor (44.8\%). A considerable majority of trainees work at a family medicine practice (87.6) and have more than 2,000 registered patients $(50.5 \%)$; on average, they see between 40 and 50 patients per day (32.4\%). $92.3 \%$ have access to their main tutor for consultation, of which $75.2 \%$ work in parallel with their main tutor. Almost a quarter of trainees had not met their regional coordinator. Fortythree percent still rotate between different practices, but they are, on average, well-equipped and have a computer 
(94.3\%) and telephone (94.3\%) available, and are provided adequate privacy $(82.9 \%)$. As a result, only $54.8 \%$ of the trainees work with a constant patient population. Apart from their regular work, $68.3 \%$ of the trainees also provide paid substitutions for other colleagues. Only slightly more than a half $(55.8 \%)$ are categorised at an appropriate pay grade and $73.3 \%$ receive a correctly calculated monthly salary.

\subsection{General satisfaction with working conditions in the practice}

On a scale of one to five, $18.1 \%(n=19)$ of FMTs rated their satisfaction with the highest rating of five and no trainees appeared to be extremely unsatisfied, as no one rated it a one. The average rate of satisfaction with working conditions in the practice was 3.8. In relative terms, most FMTs, $47.6 \%(n=50)$, rated the working conditions in the practice with a rating of four.
3.4 Analysis of satisfaction with working conditions in the practice

The following working conditions (18 to 25$)$ were not significantly associated with the general satisfaction of FMTs (Table 2).

Out of 25 working conditions, 7 are significantly associated with the trainee's general satisfaction with working conditions (Table 3).

Table 2. Working conditions not significantly associated with the general satisfaction of FMTs.

\begin{tabular}{|c|c|c|}
\hline WORKING CONDITIONS & KRUSKAL-WALLIS TEST OF DIFFERENCES & MANN-WHITNEY TEST OF DIFFERENCES \\
\hline Work location & $x 2=3.707 ; d f=3 ; p=0.295$ & $U=444.500 ; p=0.107$ \\
\hline Number of patients registered & $x 2=0.407 ; d f=2 ; p=0.816$ & $\mathrm{U}=1309.500 ; p=0.907$ \\
\hline Average daily number of patients seen & $x 2=6.525 ; d f=4 ; p=0.163$ & $U=1225.000 ; p=0.447$ \\
\hline Selected patients & & $U=1009.500 ; p=0.453$ \\
\hline Meetings with the regional coordinator & $x 2=3.786 ; d f=3 ; p=0.285$ & $U=1128.000 ; p=0.091$ \\
\hline Access to a useful computer & & $U=225.000 ; p=0.283$ \\
\hline Access to a useful telephone & & $U=184.000 ; p=0.092$ \\
\hline (Non)use of computer in the practice & & $\begin{array}{l}\mathrm{p}=0.807 \\
\text { (the latter is significantly associated with using } \\
\text { computer for email consultations, } \mathrm{p}=0.040 \text { ) }\end{array}$ \\
\hline \multirow[t]{4}{*}{ Mandatory trainings passed } & & $\begin{array}{l}\text { a. occupational safety: Mann-Whitney test } \\
\text { of differences: } U=760.500 ; p=0.293\end{array}$ \\
\hline & & $\begin{array}{l}\text { b. fire safety: Mann-Whitney test of } \\
\text { differences: } U=910.500 ; p=0.082\end{array}$ \\
\hline & & $\begin{array}{l}\text { c. training course on hospital } \\
\text { infections: Mann-Whitney test of } \\
\text { differences: } U=1142.000 ; p=0.284\end{array}$ \\
\hline & & $\begin{array}{l}\text { d. pre-employment physical exam: Mann- } \\
\text { Whitney test of differences: } U=289.000 ; p=0.976\end{array}$ \\
\hline Professional card use & $x 2=2.061 ; d f=2 ; p=0.357$ & $U=608.500 ; p=0.319$ \\
\hline Stamp use & & $U=516.500 ; p=0.652$ \\
\hline Use of an appropriate uniform & $x 2=0.204 ; d f=1 ; p=0.652$ & $U=868.500 ; p=0.101$ \\
\hline Availability of equipment at the institution & & $U=477.500 ; p=0.655$ \\
\hline Availability of equipment at the practice & & $U=252.500 ; p=0.507$ \\
\hline Internal training courses & $x 2=2.688 ; d f=3 ; p=0.442$ & $U=551.000 ; p=0.939$ \\
\hline Additional funds for education & $x 2=2.815 ; d f=3 ; p=0.421$ & $U=942.500 ; p=0.256$ \\
\hline Travel expenses allocated for modules & $x 2=3.030 ; d f=2 ; p=0.220$ & $U=705.000 ; p=0.230$ \\
\hline Correct calculation of monthly salary & $x 2=3.052 ; d f=2 ; p=0.217$ & $U=199.000 ; p=0.144$ \\
\hline
\end{tabular}


Table 3. Working conditions significantly associated with the general satisfaction of FMTs.

\begin{tabular}{lll}
\hline WORKING CONDITIONS & KRUSKAL-WALLIS TEST OF DIFFERENCES & MANN-WHITNEY TEST OF DIFFERENCES \\
\hline $\begin{array}{ll}\text { Location where work with } \\
\text { patients takes place }\end{array}$ & $\mathrm{x} 2=9.224 ; \mathrm{df}=3 ; \mathrm{p}=0.026$ & $\mathrm{U}=523.000 ; \mathrm{p}=0.017$ \\
$\begin{array}{l}\text { Privacy of premises } \\
\text { Main tutor accessibility }\end{array}$ & $\mathrm{x} 2=10.487 ; \mathrm{df}=3 ; \mathrm{p}=0.015$ & $\mathrm{U}=485.000 ; \mathrm{p}=0.006$ \\
$\begin{array}{l}\text { Constant patient population } \\
\text { Suitable place for rest }\end{array}$ & $\mathrm{x} 2=14.259 ; \mathrm{df}=5 ; \mathrm{p}=0.014$ & $\mathrm{U}=380.000 ; \mathrm{p}=0.001$ \\
$\begin{array}{l}\text { Paid out-of-hours substitutions } \\
\text { Appropriate pay grade }\end{array}$ & & $\mathrm{U}=444.000 ; \mathrm{p}=0.011$ \\
\hline
\end{tabular}

Of note, concerning the working condition "additional funds for education", the highest level of satisfaction (avg. 3.89) with working conditions was expressed by those FMTs who were not aware that there are additional funds for education available (!), while the lowest (avg. 3.33) by those whose additional funds were spent by the employers themselves.

Further contextual data to support interpretation for readers outside Slovenia is available from the authors.

\section{DISCUSSION}

The purpose of the study was to check the current working conditions of FMTs in the practical modular part of the specialist training, and to correlate working conditions with the general satisfaction of FMTs. Given the important role of family medicine in the healthcare system (32), appropriate working conditions are to be expected, including working environments in which future family medicine specialists further their education. Seven out of 25 organisational and labour law factors (location where work with patients takes place, privacy of the premises, main tutor accessibility, constant patient population, suitable place for rest, paid out-of-hours substitutions and appropriate pay grade) are significantly associated with a trainee's general satisfaction with working conditions (Table 3). The data obtained constitute a solid basis for improving the organisation and training within specialist training programmes in the future.

One of the main findings of our study is that seven out of 25 working conditions are significantly associated with the general satisfaction of FMTs with their working environment. Regarding the "location where work with patients takes place" and "privacy of premises", our results show that appropriate premises are significantly associated with the trainee's general satisfaction with working conditions. Similar studies indicate that patient privacy is also essential (3). The studies show that patient satisfaction is higher when consultations are private (25). As a result, physicians themselves are more satisfied. Our results also indicate the significance of "main tutor accessibility". It is interesting to note that trainee physicians working in person with their direct tutor achieve comparatively higher levels of satisfaction with working conditions compared to those whose main tutor is only available by phone. Similar associations regarding the improved satisfaction of medical students were likewise demonstrated in a study on a curricular reform that also entailed better access to tutors (33). "Working with a constant population" is one of the important features of a family physician's work, which is also supported by our results. Previous studies also show improved patient satisfaction when patients are always managed by the same physician (26). The consistency of care leads to a better doctor-patient relationship, which results in greater patient satisfaction (26). Some parallels are also evident with respect to a study that compared experience with specialist training between full-time and part-time employees. Satisfaction of part-time employees was lower (27). A "suitable place for rest" also proved to be an important factor for higher FMT satisfaction with working conditions. Based on the literature, which theoretically underlines the importance of a place for rest, the above result was expected (6). Regarding "paid out-of-hours substitutions", the result was also expected, since similar studies indicated increased employee satisfaction levels when overtime work or substitutions were properly paid (28). Furthermore, in our study, paid out-of-hours substitutions proved to be significantly associated with the FMTs' general satisfaction with working conditions. Like the preceding observation, the "appropriate pay grade" result can be compared to similar studies, which also indicate that the appropriate pay grade is significantly associated with satisfaction (29). Our results show that increasing levels of irregularity in calculating monthly salaries lead to decreasing trainee satisfaction with general working conditions, which is comparable to similar studies (30).

A strength of our study is its relatively large sample size, i.e. 105 out of 353 (29.75\%) of all Slovenian FMTs took part in the study. Another positive aspect is that the FMTs were highly motivated to participate in our study, i.e. 105 out of 105 (100\%) participated. Some weaknesses 
of our study might be relative subjectivity regarding the criteria for suitable working conditions in terms of spatial requirements, necessary equipment, and the requirements of the specialist training course (Table 1), although the studies conducted so far were taken into account $(3,31,34)$. Another possible disadvantage of our study is the method of sample selection (randomly chosen modular groups and regional meetings, consequently only trainees from them) and time lag from data collection to publication. We are also aware of the challenges associated with multiple statistical testing in our data set.

\section{CONCLUSION}

In our study, we investigated the current working conditions of family medicine trainees in the practical modular part of their specialist training. The study shows that even an exceptionally well-devised specialist training programme does not necessarily lead to good practical implementation. The opinions expressed by the trainees, their satisfaction with working conditions, and the implementation of the programme constitute a starting point for all stakeholders involved in the educational process of family medicine specialist training to improve the key factors for successful FMT training. The results of our study, which is the first of its kind in Slovenia, are useful for improving the existing programmes of clinical practice and family medicine specialist training, both in terms of organisation and content, in Slovenia and beyond. Our results also can be a good basis for the development of quality criteria for the accreditation of training sites. Our results are valuable in terms of investigating the family medicine trainee programmes in Slovenia, thus opening new avenues of study on this subject.

\section{ACKNOWLEDGMENTS}

The authors want to thank Ms. Smerkolj and Ms. Hadler for reviewing the English language of the manuscript, and to Prof. Zalika Klemenc Ketiš for the useful advice during the preparation of this article.

\section{DECLARATION OF INTEREST}

The authors declare that there are no conflicts of interest. The authors alone are responsible for the content and the writing of the paper.

\section{FUNDING}

This research received no specific grant from any funding agency in the public, commercial, or non-profit sectors.

\section{ETHICAL APPROVAL}

The study was approved by the National Medical Ethics Committee of the Republic of Slovenia, Decision No. 0120493/2016-2 dated 16 Feb 2017.

\section{REFERENCES}

1. Hashim MJ. A definition of family medicine and general practice. J Coll Physicians Surg Pak. 2018;28(1):76-7. doi: 10.29271/jcpsp.2018.01.76.

2. Gwynne M, Page C, Reid A, Donahue K, Newton W. What's the right referral rate? Specialty referral patterns and curricula across 13 collaborative primary care residencies. Fam Med. 2017;49(2):91-6.

3. Švab I, Rotar-Pavlič D, editors. Družinska medicina. Ljubljana: Združenje zdravnikov družinske medicine, 2012.

4. Hameed T, Zia N, Khan HS, Zia A, Ahmed R, Hameed A, et al. Analysis of level of satisfaction of postgraduate trainees on surgical floor. J Ayub Med Coll Abbottabad. 2019;31(2):207-13.

5. George MJ, Gareth RJ. Understanding and managing organizational behaviour. 6th ed. New Jersey: Prentice Hall, 2012.

6. Domagata A, Bała MM, Storman D, Peña-Sánchez JN, Świerz MJ, Kaczmarczyk M, et al. Factors associated with satisfaction of hospital physicians: a systematic review on european data. Int J Environ Res Public Health. 2018;15(11):2546. doi: 10.3390/ijerph15112546.

7. Chmielewska M, Stokwiszewski J, Filip J, Hermanowski T. Motivation factors affecting the job attitude of medical doctors and the organizational performance of public hospitals in Warsaw, Poland. BMC Health Serv Res. 2020;20(1):701. doi: 10.1186/s12913-020-05573-z.

8. Trybou J, Gemmel P, Desmidt S, Annemans L. Fulfillment of administrative and professional obligations of hospitals and mission motivation of physicians. BMC Health Serv Res. 2017;17(1):28. doi: 10.1186/s12913-017-1990-0.

9. Černetič M. Management in sociologija organizacij. Kranj: Moderna organizacija, 2007.

10. Shollen SL, Bland CJ, Center BA, Finstad DA, Taylor AL. Relating mentor type and mentoring behaviors to academic medicine faculty satisfaction and productivity at one medical school. Acad Med. 2014;89(9):1267-75. doi: 10.1097/ACM.0000000000000381.

11. Henry-Noel N, Bishop M, Gwede CK, Petkova E, Szumacher E. Mentorship in medicine and other health professions. J Cancer Educ. 2019;34(4):629-37. doi: 10.1007/s13187-018-1360-6.

12. Beaudin A, Emami E, Palumbo M, Tran SD. Quality of supervision: postgraduate dental research trainees' perspectives. Eur J Dent Educ. 2016;20(1):32-8. doi: 10.1111/eje.12137.

13. Blatt B, Plack MM, Simmens SJ. Preparing interprofessional faculty to be humanistic mentors for medical students: the GW-gold mentor development Program. J Contin Educ Health Prof. 2018;38(2):117-25. doi: 10.1097/CEH.0000000000000203.

14. Zink BJ, Hammoud MM, Middleton E, Moroney D, Schigelone A. A comprehensive medical student career development program improves medical student satisfaction with career planning. Teach Learn Med. 2007;19(1):55-60. doi: 10.1080/10401330709336624.

15. Murr AH, Miller C, Papadakis M. Mentorship through advisory colleges. Acad Med. 2002;77(11):1172-3. doi: 10.1097/00001888-20021100000042.

16. Goldstein EA, Maclaren CF, Smith S, Mengert TJ, Maestas RR, Foy $\mathrm{HM}$, et al. Promoting fundamental clinical skills: a competencybased college approach at the University of Washington. Acad Med. 2005;80(5):423-33. doi: 10.1097/00001888-200505000-00003.

17. Sambunjak D, Straus SE, Marusic A. A systematic review of qualitative research on the meaning and characteristics of mentoring in academic medicine. J Gen Intern Med. 2010;25(1):72-8. doi: 10.1007/s11606-0091165-8. 
18. Gray J, Armstrong P. Academic health leadership: looking to the future. Proceedings of a workshop held at the Canadian Institute of Academic Medicine meeting Québec, Que., Canada, Apr. 25 and 26, 2003. Clin Invest Med. 2003;26(6):315-26.

19. Frank GW. Professors not professing. JAMA. 2004;292(24):2972. doi: 10.1001/jama.292.24.2972-a.

20. Reynolds HY. In choosing a research health career, mentoring is essential. Lung. 2008;186(1):1-6. doi: 10.1007/s00408-007-9050-x.

21. Zier K, Friedman E, Smith L. Supportive programs increase medical students' research interest and productivity. J Investig Med. 2006;54(4):201-7. doi: 10.2310/6650.2006.05013.

22. Klemenc-Ketiš Z, Kersnik J. The role of the european academy of teachers in general practice and family medicine in family medicine education in Europe--the experience of the University of Maribor. Acta Med Acad. 2012;41(1):80-7. doi: 10.5644/ama2006-124.41.

23. McWhinney IR, Freeman T. Practice Management. In. McWhinney IR, editor. Textbook of family medicine. 3rd ed. Oxford: Oxford University Press, 2009:413-21.

24. Poplas Susič A, Švab I, Klemenc-Ketiš Z. Upgrading the model of care in family medicine: a Slovenian example. Public Health Panorama. 2018;(04): 550-5.

25. Olsen JC, Sabin BR. Emergency Department patient perceptions of privacy and confidentiality. J Emerg Med. 2003;25(3):329-33. doi: 10.1016/s0736-4679(03)00216-6.

26. Murray M, Davies M, Boushon B. Panel size: how many patients can one doctor manage? Fam Pract Manag. 2007;14(4):44-51.

27. Rickard C, Smith T, Scallan S. A comparison of the learning experiences of full-time (FT) trainees and less than full-time (LTFT) trainees in general practice. Educ Prim Care. 2012;23(6):399-403. doi: 10.1080/14739879.2012.11494151.

28. Green C, John SH. Does performance pay increase job satisfaction? Economica. 2008;75:710-28. doi: 10.1111/j.1468-0335.2007.00649.x

29. Heywood JS, Wei X. Performance pay and job satisfaction. J Industrial Relations. 2006;48(4):523-40. doi:10.1177/0022185606066143

30. Czypionka T, Kraus M, Mayer S, Röhrling G. Efficiency, ownership, and financing of hospitals: the case of Austria. Health Care Manag Sci. 2014;17(4):331-47. doi: 10.1007/s10729-013-9256-9.

31. Carek PJ, Anim T, Conry C, Cullison S, Kozakowski S, Ostergaard D, et al. Residency training in family medicine: a history of innovation and program support. Fam Med. 2017;49(4):275-81.

32. Poplas Susič A, Klemenc-Ketiš Z. Successful implementation of integrated care in Slovenian primary care. Zdr Varst. 2021;60(1):1-3. doi: 10.2478/sjph-2021-0001.

33. Petek Šter $M$, Cvejanov Kezunović L, Cojić $M$, Petek D, Švab I. Specialty training in family medicine in Montenegro - an evaluation of the programme by the first generation of trainees. Zdr Varst. 2018;57(2):96-105. doi: 10.2478/sjph-2018-0013.

34. Rakar G. Zadovoljstvo specializantov družinske medicine s specializacijo: specialistična naloga. Ljubljana: Medicinska fakulteta, Katedra za družinsko medicino, 2018. 